\title{
Fifty years from the publication of the first two papers on Chilean rocky intertidal assemblages: Honoring Professor Eric R. Guiler
}

Cincuenta años desde la publicación de los dos primeros trabajos sobre el intermareal rocoso de Chile: Homenaje al Profesor Eric R. Guiler

Juan Carlos Castilla ${ }^{1 *}$, D. Sc.

\begin{abstract}
${ }^{1}$ Departamento de Ecología \& Centre for Advances Studies in Ecology and Biodiversity (CASEB). Facultad de Ciencias Biológicas, Pontificia Universidad Católica de Chile, Casilla 114-D, Santiago, Chile

jcastilla@bio.puc.cl
\end{abstract}

Resumen.- En este trabajo, reviso y rindo honor a los principales hallazgos científicos del investigador australiano, Profesor Eric R. Guiler, quien en 1955 visitó las costas de Chile y realizó trabajos pioneros sobre zonaciones bióticas intermareales. Producto de ello publicó los dos primeros trabajos sobre las comunidades intermareales rocosas de Chile norte y central: Guiler 1959a, b. Además, destaco sus principales observaciones e hipótesis sobre el funcionamiento de estas comunidades en relación con sus estructuras y dinámicas. En particular, resalto las observaciones realizadas por Guiler al interior de la bahía de Antofagasta y las contrasto con trabajos experimentales de terreno recientes. Finalmente, destaco las extensas contribuciones en esta línea de investigación realizadas por investigadores chilenos y su elevado reconocimiento internacional.

Palabras clave: Primeros trabajos publicados, ensambles, especies intermareales, Chile central y norte

\section{Introduction}

Professor Eric R. Guiler, University of Tasmania, Australia, with the support of the Rockefeller Foundation and the Royal Society of Tasmania, visited the coast of central and northern Chile in the summer of 1955 . He carried out intertidal observations and worked on rocky intertidal biotic fringes, comparing Chilean intertidal patterns with those described for other latitudes. The visit was supported by Professor Parmenio Yañez, Head of the Estación de Biología Marina de Montemar, Universidad de Chile at Viña del Mar. Guiler participated in an oceanographic expedition to northern Chile, where he visited four ports on board of the Corvette Papudo under Commander P. Woolvett. Following the trip he remained at Montemar, central Chile, and carried out a series of observations on rocky intertidal biotic zoning. As a product of this work Guiler published two papers on northern and central Chile rocky shores: Guiler (1959a,

* Invited author

\begin{abstract}
In this paper I review and honor the scientific rocky intertidal findings made by the Australian investigator Professor Eric R. Guiler, who visited Chile in 1955. He pioneered this line of research in the country and published the first two papers on the Chilean rocky intertidal biotic zonation for northern and central Chile: Guiler 1959a, b. I remark Guiler's main observations and hypotheses about the structure and dynamics of these systems. I highlight the observations made by Guiler inside the Bay of Antofagasta and contrast them with recent experimental ecological work carried out inside this bay. Finally, I refer to the extensive and significant contributions made by Chilean researchers in this line of research and international recognition.
\end{abstract}

Key words: First published papers, intertidal species, assemblages, central and northern Chile

b). To the best of my knowledge these are the first two comprehensive papers published about this biotic system for Chile.

This work celebrates the 50 year publication of these papers and honors the work carried out by Guiler in Chile, under the frame of the 60 years celebration of the Revista de Biología Marina y Oceanografía. I revisit Guiler's papers and highlight key observations about the rocky shore systems in Chile, particularly those related with my own lines of research in Antofagasta and central Chile, about the structure and dynamics of rocky intertidal systems.

Professor Eric R. Guiler: A marine ecologist from the Department of Zoology, University of Tasmania, Australia and the development of rocky intertidal ecology in Chile

Early, in the decade of the 1950's, Professor Guiler started publishing on rocky intertidal biotic fringe zoning patterns in Tasmania (Guiler, 1950, 1951a,b, 1952a,b,c, 1953, 1955). 
This, undoubtedly, within the scientific framework developed by rocky intertidal pioneer ecologists as Coleman (1933), Stephenson (1936), Chapman (1938) and Doty (1946). Stephenson \& Stephenson (1949) synthesized our early knowledge about the universal features of biotic fringes between tidemarks of rocky coasts. Initially, the causes behind the biotic intertidal patterns were understood almost exclusively based on physical factors such as the tides, desiccation, isolation, wave splash, exposition or the geographical orientation of the shores. These works were continued, among others, by Lewis (1955), Pérés \& Picard (1955), Doty (1957), Southward (1958) and Guiler (1960). On turns, in the 1960 and early 1970's two rocky intertidal researchers organized and synthesized the information and contributed to the further development of this line of research: Lewis (1964) and Stephenson \& Stephenson (1972). Furthermore, rocky intertidal experimentalists appear in scene: a work represented by the papers of Connell (1961) and Paine (1966) (although many more rocky intertidal field experimentalists contributed to this approach). Now, rocky intertidal biotic interactions were exacerbated, but also combined with physical forces. Indeed, new findings in these ecological systems made a significant contribution to the development of general ecological theory (see Paine 1994).

In Chile, during the 1970 and 1980's there was an active production of rocky intertidal papers dealing with species assemblages and the ecology of community structure and dynamics. Furthermore, this research activity translated in the 1990 and 2000 into an explosive line of rocky intertidal experimental (manipulative) research in the country, overwhelmingly done by Chilean researchers. This was followed by creation (on top of the Estación de Biología Marina at Montemar Research Station, Universidad de Chile) of two new coastal marine stations and coastal reserves: The Estación Mehuín in southern Chile (Universidad Austral de Chile) and the Estación Costera de Investigaciones Marinas, Las Cruces in Central Chile (Pontificia Universidad Católica de Chile). A sample of those publications are: Alveal (1971), Alveal et al. (1973), Castilla (1976a,b), Romo \& Alveal (1977), Viviani (1979), Castilla \& Bahamonde (1979), Santelices (1980, 1981), Santelices et al. (1980, 1981), Montalva \& Santelices (1981), Oliger \& Santelices (1981), Castilla (1981, 1985), Castilla \& Moreno (1982), Moreno \& Sutherland (1982), Moreno \& Jaramillo (1983), Jara \& Moreno (1984), Moreno \& Jara (1984), Moreno et al. (1984, 1986), Santelices \& Ojeda (1984), Ojeda \& Santelices (1984a,b), Castilla \& Durán (1985), Paine et al. (1985), Bahamondes \& Castilla (1986), Castilla \& Paine (1987), Durán \& Castilla (1989) (also see reviews by Santelices 1991, Castilla 2000). In this paper I am not summarizing the major Chilean research contributions to this line of research done from the middle 1990 's to present.
To discover and understand the dynamics of biotic zoning fringes in Chilean rocky shore systems has been for me a fascinating scientific trip. Therefore, it has not been difficult, even though I did not meet Professor Guiler, to imagine his excitement in the rocky shores of this country more than 50 years ago. Also, it has been easy to understand the support of the Rockefeller Foundation to Guiler's trip to Chile, since the same Foundation enthusiastically supported Patricio Sánchez Reyes (P. Universidad Católica de Chile; Castilla \& Santelices 1999) to develop marine coastal research and the training of young scientists in Chile (1960-1967). Among the important lessons in this area of research in Chile we have learned along these years is that the development of basic, elemental and solid science, has truly served the country and society, not only via the development of new ideas and the test of ecological hypotheses (as examples, see Santelices 1991, Power et al. 1996, Castilla 2000), but for the science of marine conservation and the rational use of marine coastal resources (Castilla et al. 1998a, Castilla \& Fernández 1998, Castilla \& Gelcich 2008).

\section{Professor Guiler in Chile: Oceanographic expedition to northern Chile}

In the summer of 1955 Professor Guiler, on board of the Papudo Corvette, left Valparaíso, as part of a northern Chile (Valparaíso - Arica) oceanographic expedition organized by the Estación de Biología Marina de Montemar and financed by the Corporación de Fomento de la Producción (CORFO), in the company of Professor P. Yañez. The Papudo, in its expedition made short stops at four ports: Coquimbo (20 $20^{\text {th }}$ February), Antofagasta ( $22^{\text {nd }}$ February), Iquique (25 ${ }^{\text {th }}$ February) and Arica (26-28 ${ }^{\text {th }}$ February), and in its return to Valparaíso at Antofagasta ( $2^{\text {nd }}$ March). The main objectives of the expedition were to obtain oceanographic information, but Guiler went ashore and visited and worked in the rocky shores around the mentioned ports. His paper, Guiler (1959a), is the product of those visits. He published, for the first time, comprehensive descriptions of the biotic assemblages in those rocky shores, as well as their biotic zoning patterns. Further, in his paper he reviewed and commented the known literature on Chilean oceanic currents, winds, salinity and tides of northern Chile, making comparisons with the information at hand from Peru and other latitudes.

\section{Professor Guiler in the Antofagasta's intertidal rocky shore: Six key observations}

As a result of my own scientific work on the structure and dynamics of rocky shores inside the Bay of Antofagasta (Castilla \& Guiñez 2000, Castilla et al. 2000, 2004) I have decided to concentrate the analysis of Guiler 

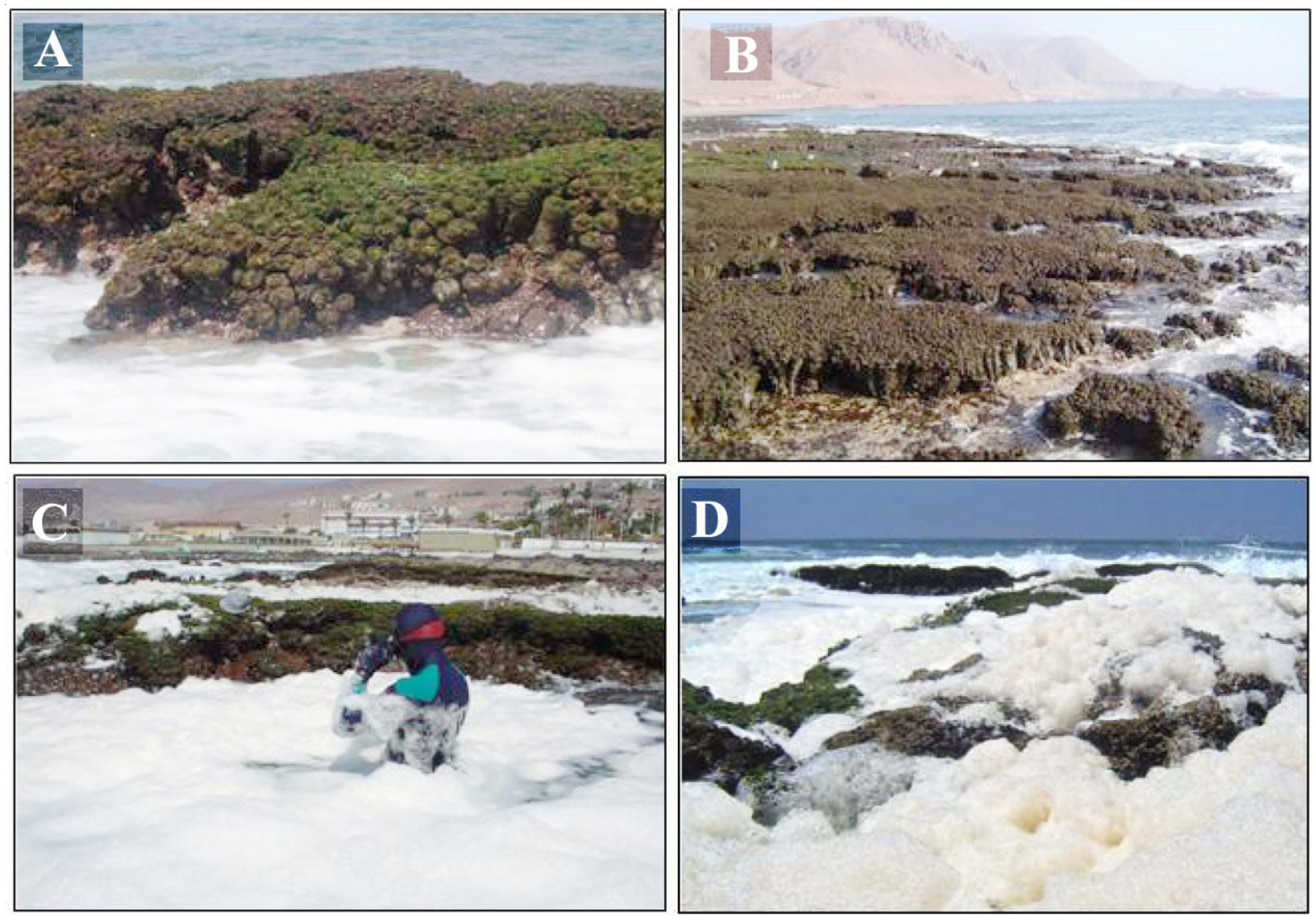

Figure 1

Dense matrices of Pyura praeputialis in the rocky intertidal of Antofagasta (low tide) A = at AAA platforms (see text); $B=$ at EI Way platforms. $C$ and $D=$ formation of biofoam in intertidal pools and rocky shores on top of Pyura matrices (Castilla et al. 2007)

Matrices densas de Pyura praeputialis en el intermareal rocoso de Antofagasta (marea baja). A = en plataformas de AAA (ver texto); $\mathrm{B}=$ en plataformas de $\mathrm{El}$ Way. $\mathrm{C}$ and $\mathrm{D}=$ formación de bio-espuma en pozas intermareales en los roqueríos sobre las matrices de Pyura (Castilla et al. 2007)

(1959a) paper on six observations he made when working on the rocky intertidal platforms inside this bay. These observations and hypotheses formulation (made more than 50 years ago) on the structure and possible dynamic interactions regarding the unique intertidal biotic system inside the Bay of Antofagasta, have always amazed me. They were done just based on a few tidal excursions. Guiler's observations were keen and the questions asked very inquisitive. Guiler included a photograph of the rocky shores he worked at Antofagasta (22 ${ }^{\text {nd }}$ February, 1955), the so called Playa Blanca, opposite to the Artillery Barracks, beyond the southern end of the town (at that time), on the road to the Automobile Club of Antofagasta (Asociación Automovilística de Antofagasta, AAA). In this paper I am including four photographs taken in the
Antofagasta rocky intertidal shores, close to the sites worked by Guiler (Fig. 1A, B, C, and D). In my view the following six observations, descriptions and hypotheses, are worth to be distinguished from Guiler (1959a) paper:

Observation 1. On describing the rocky intertidal zonation at Antofagasta, Guiler (1959a, pp. 46-47) highlights the unique presence of a dense intertidal covering of an ascidia (Fig. 1A, B) and a red turf coralline: Pyura-Corallina belt, that replaces the traditional intertidal barnacle belt present in other intertidal localities in Chile (we can deduce that he also referred this covering as replacing the mussel intertidal belt, see p. 49). He wrongly identified the ascidia as Pyura chilensis. The species was rightly identified, more than 55 years later, by Castilla et al. (2002a), as Pyura preaputialis. Further, 
Guiler (1959a) indicates that the ascidia may be considered as an intertidal indicator of warm water conditions, pointing out that in warm temperate seas in Australia, an ascidia as this one, also forms intertidal extensive and ecologically very similar belts. Indeed, Castilla et al. (2002a) based on DNA analyses showed that the Australian and the Antofagasta intertidal Pyura were the same species, most probably having arrived to the Antofagasta Bay from Australia. The pronounced presence of this biotic belt in Antofagasta along miles of the rocky shore, and its inland (supralittoral) extension was also highlighted by Guiler. The uniqueness in Chile, of this intertidal belt formation scheme, found exclusively inside this bay, powerfully called Guiler's attention.

Observation 2. Guiler (1959a) described how the Antofagasta Pyura individuals were closely (Fig. 1A) united into coalesced masses offering strong resistance to wave action, and how the space between the ascidians and the rock offered shelter and habitat for more delicate organisms: which it may be interpreted as suggesting an intertidal increase of microhabitats and local biodiversity. He indicated that species such as the loco Concholepas concholepas, chitons and key-hole limpets were fairly common in the infralittoral fringe as well as under the Pyura beds. Cerda \& Castilla (2001) and Castilla et al. (2004) showed that indeed the Antofagasta Pyura matrices generated a new tridimensional microhabitat that enhances local invertebrate biodiversity (and biomass) inside the bay, as compared with sites from outside the bay.

Observation 3. Guiler (1959a) based on preliminary meteorological observations in the port of Antofagasta concluded that there were physical factors inside the bay that produced somewhat warmer conditions at sites on either side of the bay. This is a remarkable observation, since recently and using remote sensing techniques, it was demonstrated the existence, inside the Bay of Antofagasta, of one of the strongest and more persistent upwelling shadows occurring along the southeastern Pacific coast (for upwelling shadows see Graham et al. 1992, Graham 1993, Graham \& Largier 1997), and which translates in an increase of the temperature of the bay's water of up to $2-3^{\circ} \mathrm{C}$. Moreover, Escribano \& Hidalgo (2001) and Castilla et al. (2002) demonstrated the existence of cyclonic circulation inside the Bay of Antofagasta and suggested this as a retentive mechanism, which may help plankton retention, and leading to spatial variation in recruitment of intertidal invertebrates (Lagos et al. 2008)

Observation 4. One of the most important observations made by Guiler (1959a), during the two days visit to Antofagasta's rocky shores, was the description of the shore being covered with an abundant white foam: 'which acts as a very efficient protection from the sun and filled the clefts and gulley in the rocks and covered all the shore from top of the barnacle belt down... and wave actions did not disturbed it'. Guiler included a photograph $\left(22^{\text {nd }}\right.$ February, 1955) illustrating de white foam deposited on intertidal rocks in front of the Artillery Barracks. Interestingly, Castilla et al. (2007) re-described the existence of abundant biofoams on the rocky shores of Antofagasta (Fig. 1C, D), resulting from the synchronous mass spawning of Pyura praeputialis, both male and female gametes, into aerated and turbulent inshore waters. It was experimentally demonstrated that Pyura gametes decreased the surface tension of the water, inducing the formation of the biofoam, which enhanced Pyura fertilization success and larval retention on the rocky shore inside the bay.

Observation 5. Guiler (1959a) observed that the Pyura belt extended from the midlittoral down to the infralittoral fringe, commenting that in other localities in northern Chile the infralittoral fringe is dominated by the large Pheophyceae Lessonia nigrescens (while in central Chile is also present Durvillaea antarctica, 'cochayuyo'). He offered two explanations for this species replacement: a) That in the Bay of Antofagasta there exist some set of local conditions which do not favor the growth of large Pheophycea in the infralittoral fringe; b) That some catastrophe befell these algae (it may have been El Niño?) and that they were replaced in the shore by the ascidians, which became so numerous that the algae were unable to compete in their accustomed habitat. Guiler specifically argued about the possibility of Pyura outcompeting Lessonia (also see Paine 1986). So far, our own observations (unpublished results) indicate that Lessonia kelps transplanted (see Lessonia transplanting techniques in Correa et al. 2006) from sites outside the Bay of Antofagasta to intertidal rocks inside the bay, show a significant reduction in growth, survival and photosynthesis, expressed as enhanced photoinhibition and low recovery capacity, after light stress; when compared with Lessonia kelps simultaneously transplanted outside the bay. In Antofagasta, we have not yet explore direct competition interactions between Pyura and Lessonia.

Observation 6. Obviously, the unique Chilean-Peruvian muricid gastropod Concholepas concholepas did not escape Guiler's curiosity. He described its presence in the rocky infralittoral and sublittoral fringes of Antofagasta and recognized that as the species approaches the northern ends of its range (northern Chile and the border with Peru) decreases in size, as compared with central and southern Chile specimens. Nevertheless, ecologically, he mistakenly thought that Concholepas was 
an algae grazer and that in Chile this mollusk appeared to fill the niche of Haliotis. Nevertheless, it has to be taken into account that only about 25 years later Castilla and collaborators produced solid evidence for the carnivore status of C. concholepas (Castilla \& Guisado 1979, Castilla et al. 1979). Furthermore, it took another 15-20 years to demonstrate the key-stone species ecological role of Concholepas in Chilean rocky shores (Castilla \& Durán 1985, Power et al. 1996, Castilla 1999).

\section{Professor Guiler in central Chile rocky shores: Montemar and nearby sites}

I have been unable to obtain information about Guiler's stay in Montemar, even the time he worked at the Marine Biological Station of Montemar, one of the first marine coastal stations established in South America in 1948 (including an intertidal reserve zone, Castilla 1996). Professor Nibaldo Bahamonde remembers Guiler 'as a tall, thin and gentle Australian marine shore researcher'. They interchanged letters about Chilean invertebrate taxonomical aspects. Nevertheless, what it can be said is that Guiler spent enough time at Montemar and surrounding shores to produce his second paper about the Chilean intertidal rocky shores: Guiler (1959b), specifically on the Montemar area (ca. 32 $57^{\prime} \mathrm{S}$, $\left.71^{\circ} 33^{\prime} \mathrm{W}\right)$. He analyzed tidal, oceanographic, hydrological and climatic information for the area and carried out rocky intertidal biotic zonations in exposed and sheltered rocky sites. He called the attention that in central Chile the rocky shores were extremely exposed. He stated that by sheltered he meant sites 'sheltered from the main forces of the waves'. Indeed, this a characteristic for most of the rocky shore sites in central Chile, along hundred of kilometers (Castilla et al. 1998b). Guiler described the rocky shore biotic fringes with details and presented the first rocky intertidal fringe zoning kite-like figure (Guiler 1959 b, p. 178).

In this section I would like to highlight a series of intertidal biotic fringe zoning observations and comparative analyses between the Montemar shore and nearby sites, north and south of Montemar, carried out by Guiler. Similar observations were done later on, independently, by me and students (also in central Chile rocky shores), and they form part of the core of my lines of research. Moreover, some of those key observations lead me to the establishment of the Estación Costera de Investigaciones Marinas, Las Cruces, in 1982 (Castilla 1996). Guiler (1959b, pp. 179-181) described rocky intertidal assemblages for two interesting sites: Laguna Verde (ca. $20 \mathrm{~km}$ south of Montemar) and Punta Curaumilla ( $c a .10 \mathrm{~km}$ south of Laguna Verde), at that time 'only accessible by walking or by transport over a very rough road', (this is to say with little or no human interference). Guiler indicates that in the infralittoral, about $1 \mathrm{~km}$ south of Laguna Verde, the intertidal zonation changes sharply. Among other observations, he reports that the Lessonia nigrescens belt is becoming replaced by a belt of Durvillaea antarctica (in Chile an edible macroalgae). Nevertheless, Lessonia continues present only in relatively shelter zones, particularly in those behind beds of Macrocystis pyrifera. He suggests, correctly, that subtidal shallow Macrocystis beds may exert a considerable effect in lowering the strength of the waves on the rocky shore. Nevertheless, south of Punta Curaumilla, Durvillaea becomes very common and is the dominant kelp in the infralittoral fringe. The dominance of Durvillaea in this fringe is also reported for Las Ventanas (ca. $25 \mathrm{~km}$ north of Montemar), a site also with a strong wave action; nevertheless, at Pichidangui (ca. $120 \mathrm{~km}$ north of Montemar), a site also with strong wave action, the dominance goes back to Lessonia. Guiler then asks the question: Why then is D. antarctica almost absent form the Laguna Verde-Montemar-Quinteros area? He rejects two hypotheses: a) That the exposure and wave strength may be the cause, since wave action at Montemar is much stronger that for instance in Laguna Verde; b) That the influence of fresh water may be the cause, since in the studied area that influence is negligible, tough may be important at Concon. He concluded, rightly, that the only factor offering any explanation of this peculiarity in the distribution and dominance of $D$. antarctica, between Punta Curaumilla and Pichidangui (ca. $200 \mathrm{~km}$ of coast line) would be the effect of human interference, since Durvillaea is in considerable demand for food. Guiler suggests the existence of a strong competition between the two species of algae and baptized $D$. antarctica as a 'wave action loving species'. Several decades after, in the 80 and 90's, several ecologists in Chile tackled these and related problems (i.e., Santelices et al. 1980). Furthermore, Castilla \& Bustamante (1989), Bustamante \& Castilla (1990) re-addressed the human interference/ exploitation hypothesis regarding populations of $D$. antarctica in central Chile (actually they used Punta Curaumilla as a focal study area). More recently, Castilla et al. (2007) have demonstrated that human exploitation heavily diminished populations of $D$. antarctica in central Chile rocky shores, and that the populations may be reestablished, provided human extraction is strictly controlled.

A second careful observation made by Guiler (1959b) at Montemar refers to one of the most remarkable fishes, Syciases sanguineus ('pejesapo'). Syciases is transported by waves and is found on steep-sloping rocks in exposed crevices and gullies. The fish clings to the rocks, when the strong surf recedes, using a ventral powerful sucker 


\section{Table 1}

List of intertidal algae and invertebrates recorded by Guiler (1959a, b). Species in parenthesis are no valid combinations; valid combinations are included below the parenthesis

Listado de especies de algas e invertebrados intermareales en Guiler (1959a, b). Las especies entre paréntesis son combinaciones no válidas; las combinaciones válidas son indicadas abajo del paréntesis

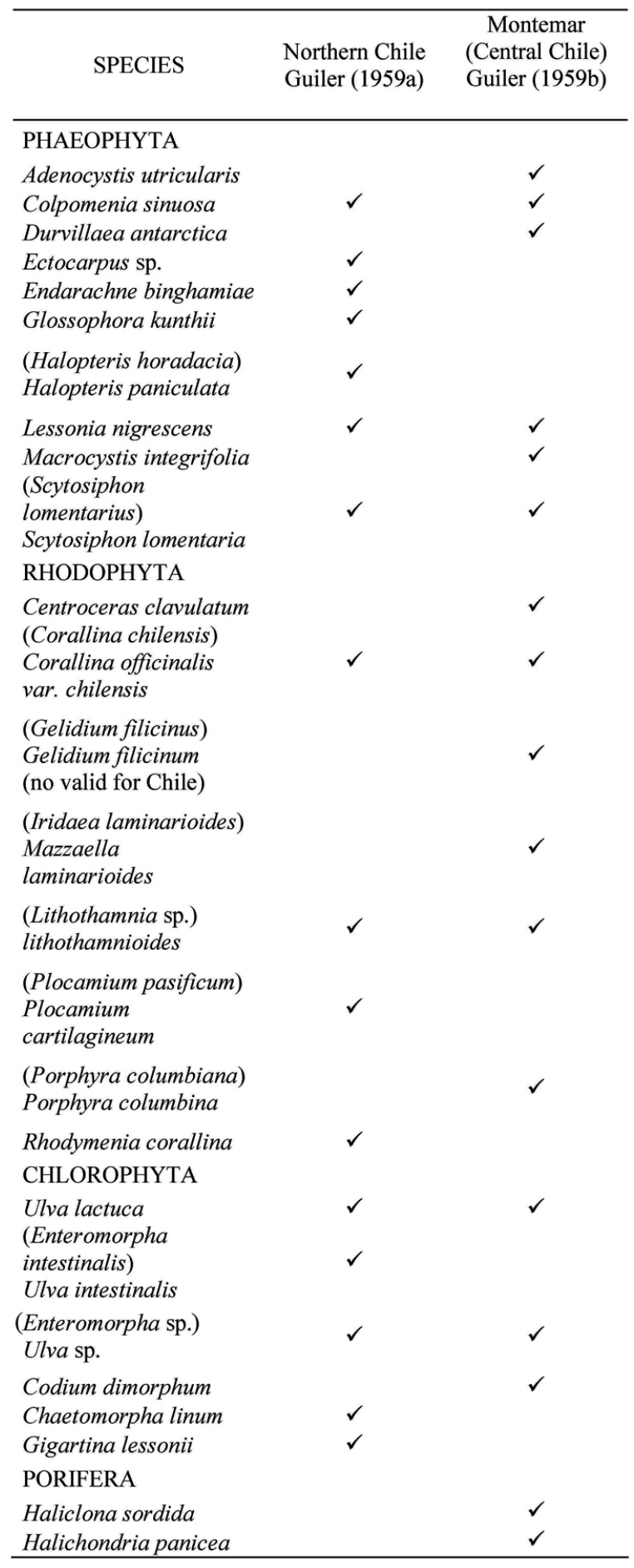

\begin{tabular}{ccc}
\hline & & Montemar \\
SPECIES & Northern Chile & (Central Chile) \\
& Guiler (1959a) & Guiler (1959b)
\end{tabular}

\section{CNIDARIA \\ (Sagartia chilensis) \\ Anthothöe chilensis \\ (Phymactis clematis) \\ Phymactis papillosa \\ POLYCHAETA \\ Potamilla sp. \\ Cirriformia sp. \\ Dasybranchus sp. \\ (no valid for Chile) \\ Demonax sp. \\ Eulalia personata (no valid for Chile) \\ Euphrosine sp.}

Halosydna fuscomarmorata (no valid for Chile)

Hemipodus simplex

Lepidasthenia virens

Lumbrineris sp.

Lumbrineris tetraura

Marphysa sanguinea

(no valid for Chile)

Nereis grubei

Nerides $\mathrm{sp}$.

(no valid for Chile)

Pherusa sp.

Phragmatopoma moerchi

Platynereis magalhaensis

Pseudonereis gallapagensis

Scoloplos sp.

Spirorbis sp.

Thelepus concinnatus (no valid for Chile)

Thelepus sp.

MOLLUSCA

Acanthopleura echinata

(Chiton latus)

Chiton magnificus

Chiton cumingsi

Chiton granosus

Chaetopleura peruviana

Enoplochiton niger

(Acmaea sp.)

Scurria sp. 
(Table 1 Cont.)

\begin{tabular}{lcc}
\hline \multicolumn{1}{c}{ SPECIES } & $\begin{array}{c}\text { Northern Chile } \\
\text { Guiler (1959a) }\end{array}$ & $\begin{array}{c}\text { Montemar } \\
\text { (Central Chile) }\end{array}$ \\
Guiler (1959)
\end{tabular}

and can tolerate thermal stress and desiccation. Guiler described Syciases feeding on algae attached to the rocks using powerful incisor teeth. Emersion behavior of this extraordinary Gobiesocidae fish and its foraging ecology where tackled later on by Paine \& Palmer (1978). S. sanguineus is a unique trophic generalist, which consumes at least 17 species of macroalgae and 43 species of invertebrate (Cancino \& Castilla 1988).

\section{Species of intertidal macroalgae and invertebrates identified by Guiler (1959 a,b) in Chile}

Table 1 shows the list of species of intertidal macroalgae

\begin{tabular}{|c|c|c|}
\hline SPECIES & $\begin{array}{l}\text { Northern Chile } \\
\text { Guiler (1959a) }\end{array}$ & $\begin{array}{c}\text { Montemar } \\
\text { (Central Chile) } \\
\text { Guiler (1959b) }\end{array}$ \\
\hline $\begin{array}{l}\text { Leptograpsus variegatus } \\
\text { Acanthocyclus gayi } \\
\text { Acanthocyclus hassleri } \\
\text { Amphoroidea typa }\end{array}$ & $\checkmark$ & $\begin{array}{l}\checkmark \\
\checkmark \\
\checkmark\end{array}$ \\
\hline $\begin{array}{l}\text { (Cancer polyodon) } \\
\text { Cancer setosus }\end{array}$ & $\checkmark$ & \\
\hline $\begin{array}{l}\text { Pachycheles grossimanus } \\
\text { Pagurus edwardsi } \\
\text { Paraxanthus barbiger }\end{array}$ & $\checkmark$ & $\begin{array}{l}\checkmark \\
\checkmark \\
\checkmark\end{array}$ \\
\hline $\begin{array}{l}\text { (Petrolisthes angulosus) } \\
\text { Allopetrolisthes angolosus }\end{array}$ & $\checkmark$ & $\checkmark$ \\
\hline Petrolisthes tuberculatus & $\checkmark$ & \\
\hline $\begin{array}{l}\text { (Petrolisthes spinifrons) } \\
\text { Allopetrolisthes spinifrons }\end{array}$ & & $\checkmark$ \\
\hline $\begin{array}{l}\text { (Petrolisthes patagonicus) } \\
\text { Liopetrolisthes patagonicus }\end{array}$ & $\checkmark$ & \\
\hline Taliepus dentatus & & $\checkmark$ \\
\hline $\begin{array}{l}\text { (Gaudichaudia gaudichaudii) } \\
\text { Gaudichaudia gaudichaudi }\end{array}$ & $\checkmark$ & \\
\hline Pilumnoides perlatus & $\checkmark$ & $\checkmark$ \\
\hline $\begin{array}{l}\text { (Pinnotheres chilensis) } \\
\text { Pinnaxodes chilensis }\end{array}$ & & $\checkmark$ \\
\hline $\begin{array}{l}\text { (Pisoides edwardsii) } \\
\text { Pisoides edwardsi }\end{array}$ & & $\checkmark$ \\
\hline $\begin{array}{l}\text { Platypodiella sp. } \\
\text { (no valid for Chile) }\end{array}$ & & $\checkmark$ \\
\hline Betaeus emarginatus & & $\checkmark$ \\
\hline Synalpheus spinifrons & & $\checkmark$ \\
\hline Emerita analoga & & $\checkmark$ \\
\hline Rhynchocinetes typus & $\checkmark$ & $\checkmark$ \\
\hline ECHINODERMATA & & \\
\hline $\begin{array}{l}\text { Loxechinus albus } \\
\text { Tetrapygus niger }\end{array}$ & $\checkmark$ & $\checkmark$ \\
\hline Meyenaster gelatinosus & & $\checkmark$ \\
\hline Patiria chilensis & & $\checkmark$ \\
\hline Patiriella sp. & & $\checkmark$ \\
\hline Stichaster striatus & $\checkmark$ & $\checkmark$ \\
\hline Heliaster helianthus & $\checkmark$ & \\
\hline ASCIDEACEA & & \\
\hline Pyura chilensis & $\checkmark$ & $\checkmark$ \\
\hline
\end{tabular}

and invertebrates identified by Guiler (1959a,b), as product of field trips during the oceanographic expedition to four ports of northern Chile and those for the coast of central Chile (Punta Curaumilla to Pichidangui). In Guiler's species' identification endeavor he was helped by Chilean and foreign taxonomists. He mentions taxonomical expertise received in the Montemar Station from Professors P. Yañez and H. Etcheverry and from international institutions from Drs. O. Hartman, D. P. Henry, L. B. Holthuis, M. Burton, F.A. Chance, D. Ingram and I. Bowman.

In the first column of Table 1 there is a list the species 
recorded by Guiler (1959a) in northern Chile shores: 16 species of macroalgae and 55 species of invertebrates. In the second column are those recorded by Guiler (1959b) from central Chile shores: 17 species of macroalgae and 58 species of invertebrates. When possible, I have indicated known changes of specific denominations. Most probably, this is the first list of intertidal macroalgae and invertebrate assemblages published for the central and northern coast of Chile. Before, the Lund-Chile expedition to southern Chile (Brattström \& Dahl 1951) had completed a comprehensive survey of the marine biota, particularly south of $40^{\circ} \mathrm{S}$.

\section{Final remarks}

It is my view that these two papers of Guiler $(1959 a, b)$ on the Chilean intertidal rocky ecosystems did set part of the stage for the future development of this discipline in the country, which 50 years later shows a strong school of thought and has received international recognition. Professor Eric. R. Guiler was a sharp rocky intertidal observer. He knew the discipline, most probably enjoyed field work, and in no doubt was inspired by the great school of thought of intertidal ecologists of that time. More than that, undoubtedly he formed part of the 1940's and 1950's rocky intertidal scientific school of thought. Looking back, we as future Chilean rocky intertidal ecologists, profited enormously from Guiler's visit to Chile, above all due to the formulation of advanced and challenging hypotheses on the structure and dynamics of northern and central Chile rocky shore assemblages. It is more than proper to honor the 50 year anniversary of Eric R. Guiler (1959a, b)'s rocky intertidal papers.

\section{Acknowledgments}

I sincerely thanks Bernardita Campos for her kind invitation to write a paper for the celebration of the 60 years of the Revista de Biología Marina y Oceanografia of Montemar. Luis Prado, Verónica Ortiz, Bernabé Santelices, Nicolás Rozbaczylo, Alejandra González, Patricio Zabala, Karina Vergara and Matías Frugone helped me with the actualization of the intertidal species listed reported by Guiler (1959a,b). Stefan Gelcich and Patricio Manríquez read the $\mathrm{ms}$ and suggested modifications. I sincerely appreciate suggestions made by an anonymous referee.

\section{Literature cited}

Alveal K. 1971. El ambiente costero de Montemar y su expresión biológica. Revista de Biología Marina 14: 85-119.

Alveal K, H Romo \& J Valenzuela. 1973. Consideraciones ecológicas de las regiones de Valparaíso y de Magallanes. Revista de Biología Marina 15(1): 1-30.
Bahamondes I \& JC Castilla. 1986. Predation of marine invertebrates by the Kelp Gull Larus dominicanus in an undisturbed intertidal rocky shore of Central Chile. Revista Chilena de Historia Natural 59: 65-72.

Brattström H \& E Dahl. 1951. Reports of the Lund University Chile Expedition 1948-1949. I. General account, list of stations, hydrography. Lunds Universities Arsskrift NF Avd. 2, 46: 188 .

Bustamante R \& JC Castilla. 1990. Impact of human exploitation on populations of the intertidal southern Bull-Kelp Durvillaea antarctica (Phaeophyta, Durvilleales) in Central Chile. Biological Conservation 52: 205-220.

Cancino JM \& JC Castilla. 1988. Emersion behavior and foraging ecology of the common Chilean clingfish Syciases sanguineus (Pisces: Gobiesocidae). Journal of Natural History 22: $249-261$.

Castilla JC. 1976a. Parques y Reservas Marinas Chilenas: necesidad de creación, probables localizaciones y criterios básicos. Medio Ambiente 2: 70-80.

Castilla JC. 1976b. Ecosistemas Marinos en Chile: Principios generales de clasificación. In: Orrego F (ed). Preservación del Medio Ambiente Marino, pp. 22-37. Editorial Universidad Técnica del Estado, Santiago de Chile.

Castilla JC. 1981. Perspectivas de investigación en estructura y dinámica de comunidades intermareales rocosas de Chile Central. II. Depredadores de alto nivel trófico. Medio Ambiente 5: $190-215$.

Castilla JC. 1985. Food webs and functional aspects of the kelp, Macrocystis pyrifera, community in the Beagle Channel, Chile. In: Siegfried WR, PR Condy \& RM Laws (eds). Antarctic Nutrient Cycles and Food Webs, pp. 407-414. Springer-Verlag, Berlin.

Castilla JC. 1996. La futura red chilena de parques y reservas marinas y los conceptos de conservación, preservación y manejo en la legislación nacional. Revista Chilena de Historia Natural 69: 253-270.

Castilla JC. 1999. Coastal marine communities: trends and perspectives from human-exclusion experiments. Trends in Ecology and Evolution 14: 280-283.

Castilla JC. 2000. Roles of experimental marine ecology in coastal management and conservation. Journal of Experimental Marine Biology and Ecology 250: 3-21.

Castilla JC \& N Bahamonde. 1979. Observaciones conductuales y ecológicas sobre Lutra felina (Molina) 1782 (Carnívora: Mustelidae) en la zona Central y Centro Norte de Chile. Archivos de Biología y Medicina Experimentales 12: 119132.

Castilla JC \& R Bustamante. 1989. Human exclusion from intertidal rocky shore of Las Cruces, Central Chile: Effects on Durvillaea antarctica (Phaeophyta, Durvilleales). Marine Ecology Progress Series 50: 203-214.

Castilla JC \& LR Durán. 1985. Human exclusion from the rocky intertidal zone of Central Chile: The effects on Concholepas concholepas (Gastropoda). Oikos 45: 391-399. 
Castilla JC \& M Fernández. 1998. Small-scale benthic fisheries in Chile: On co-management and sustainable use of benthic invertebrates. Ecological Applications 8: 124-132.

Castilla JC \& S Gelcich. 2008. Management of the loco (Concholepas concholepas) as a driver for self-governance of small-scale benthic fisheries in Chile. In: Townsend R, R Shotton \& H Uchida (eds). Case studies in fisheries selfgovernance. FAO Fisheries Technical Paper 504: 441-451.

Castilla JC \& R Guiñez. 2000. Disjoint geographical distribution of intertidal and nearshore benthic invertebrates in the Southern Hemisphere. Revista Chilena de Historia Natural 73: 586-603.

Castilla JC \& Ch Guisado. 1979. Conducta de alimentación nocturna de Concholepas concholepas (Mollusca: Gastropoda: Muricidae). Biología Pesquera 12: 125-130.

Castilla JC \& CA Moreno. 1982. Sea urchins and Macrocystis pyrifera: experimental test of their ecological relationships in Southern Chile. In: Lawrence JM (ed). Proceedings of the International Echinoderm Conference, Tampa Bay, pp. 257263. AA Balkena Press, Rotterdam.

Castilla JC \& RT Paine. 1987. Predation and community organization on Eastern Pacific, temperate zone, rocky intertidal shores. Revista Chilena de Historia Natural 60: 131151.

Castilla JC \& B Santelices. 1999. Obituario Patricio Sánchez Reyes (1928-1999). Revista Chilena de Historia Natural 72: 147-151.

Castilla JC, MA Campo \& RH Bustamante. 2007. Recovery of Durvillaea antarctica (Durvilleales) inside and outside Las Cruces Marine Reserve, Chile. Ecological Applications 17: 1511-1522.

Castilla JC, AG Collins, CP Meyer, R Guiñez \& DR Linberg. 2002a. Recent introduction of the dominant tunicate, Pyura praeputialis (Urochordata, Pyuridae) to Antofagasta, Chile. Molecular Ecology 11: 1579-1584.

Castilla JC, Ch Guisado \& J Cancino. 1979. Aspectos ecológicos y conductuales relacionados con la alimentación de Concholepas concholepas (Mollusca: Gastropoda: Muricidae). Biología Pesquera 12: 99-114.

Castilla JC, R Guiñez, JL Alvarado, C Pacheco \& M Varas. 2000. Distribution, population structure, population biomass and morphological characteristics of the tunicate Pyura stolonifera in the Bay of Antofagasta, Chile. Marine Ecology 21: 161-174.

Castilla JC, R Guiñez, A Caro \& V Ortiz. 2004. Invasion of a rocky shore by the tunicate Pyura praeputialis in the Bay of Antofagasta, Chile. Proceedings of the National Academy of Sciences 101: 8517-8524.

Castilla JC, N Lagos \& M Cerda. 2004. Marine ecosystem engineering by the alien ascidian Pyura praeputialis on an intertidal rocky shore. Marine Ecology Progress Series 268: 119-130.

Castilla JC, NA Lagos, R Guiñez \& JL Largier. 2002b. Embayments and nearshore retention of plankton: the Antofagasta Bay and other examples. In: Castilla JC \& JL Largier (eds). The Oceanography and Ecology of the
Nearshore and Bays in Chile, pp. 179-203. Ediciones Universidad Católica de Chile, Santiago de Chile.

Castilla JC, P Manríquez, J Alvarado, A Rossón, C Pino, C Espóz, R Soto, D Oliva \& O Defeo. 1998a. Artisanal Caletas: as units of production and co-managers of benthic invertebrates in Chile. Canadian Journal of Fisheries and Aquatic Sciences, Special Publication 125: 407-413.

Castilla JC, PH Manríquez, A Delgado, L Gargallo, A Leiva \& D Radic. 2007. Bio-foam enhances larval retention in a free-spawning marine tunicate. Proceedings of the National Academy of Sciences 104: 18120-18122.

Castilla JC, DK Steinmiller \& CJ Pacheco. 1998b. Quantifying wave exposure daily and hourly on the intertidal rocky shore of Central Chile. Revista Chilena de Historia Natural 71: 1925.

Cerda M \& JC Castilla. 2001. Diversity and biomass of macroinvertebrates in intertidal matrices of the tunicate Pyura praeputialis (Heller, 1878) in the Bay of Antofagasta, Chile. Revista Chilena de Historia Natural 74: 841-853.

Coleman J. 1933. The nature of intertidal zonation of plants and animals. Journal of the Marine Biological Association of the United Kingdom 18: 435-476.

Connell JH. 1961. Effects of competition, predation by Thais lapillus, and other factor son natural populations of the barnacle Balanus balanoides. Ecological Monographs 31: 61-104.

Correa JA, NA Lagos, MH Medina, JC Castilla, M Cerda, M Ramírez, E Martínez, S Faugeron, S Andrade, R Pinto \& L Contreras. 2006. Experimental transplants of the large kelp Lessonia nigrescens (Phaeophyceae) in high-energy wave exposed rocky intertidal habitats of northern Chile: experimental, restoration and management applications. Journal of Experimental Marine Biology and Ecology 335: 13-18.

Chapman RW. 1938. The tides of Australia. Official Year Book of Commonwealth of Australia 31: 972-994.

Doty MS. 1946. Critical tide factors that are correlated with the vertical distribution of marine algae and other organism along the Pacific coast. Ecology 27: 315-328.

Doty MS. 1957. Rocky intertidal surfaces. Geological Society of America Memoir 67: 535-585.

Durán RL \& JC Castilla. 1989. Variation and persistence of middle rocky intertidal community of Central Chile with and without human harvesting. Marine Biology 103: 555562.

Escribano R \& P Hidalgo. 2001. Circulación inducida por el viento en Bahía de Antofagasta, norte de Chile $\left(23^{\circ} \mathrm{S}\right)$. Revista de Biología Marina y Oceanografía 36: 43-60.

Graham WM. 1993. Spatio-temporal scale assessment of an 'upwelling shadow' in northern Monterrey Bay, California. Estuaries 16: 83-91.

Graham WM \& JL Largier. 1997. Upwelling shadows as nearshore retention sites: the example of Monterrey Bay. Continental Shelf Research 17: 509-532. 
Graham WM, JG Field \& DC Potts. 1992. Persistent 'upwelling shadows' and their influence on zooplankton distributions. Marine Biology 114: 561-570.

Guiler ER. 1950. The intertidal ecology of Tasmania. Paper and Proceedings of the Royal Society of Tasmania 84: 135201.

Guiler ER. 1951a. The intertidal ecology of Pipe Clay Lagoon. Paper and Proceedings of the Royal Society of Tasmania 85: 29-52.

Guiler ER. 1951b. Notes on the intertidal ecology of the Freycinet Peninsula. Paper and Proceedings of the Royal Society of Tasmania 85: 53-70.

Guiler ER. 1952a. The ecological features of certain sheltered intertidal areas in Tasmania. Paper and Proceedings of the Royal Society of Tasmania 86: 1-11.

Guiler ER. 1952b. The intertidal ecology of Eaglehawk Neck. Paper and Proceedings of the Royal Society of Tasmania 86: $13-29$

Guiler ER. 1952c. The nature of intertidal zonation in Tasmania. Paper and Proceedings of the Royal Society of Tasmania 86: 31-61.

Guiler ER. 1953. Intertidal classification in Tasmania. The Journal of Ecology 41: 381-384.

Guiler ER. 1955. Australian intertidal belt-forming species in Tasmania. The Journal of Ecology 43: 138-148.

Guiler ER. 1959a. Intertidal belt-forming species on the rocky coasts of northern Chile. Papers and Proceedings of the Royal Society of Tasmania 93: 33-58.

Guiler ER. 1959b. The intertidal ecology of the Montemar area, Chile. Papers and Proceedings of the Royal Society of Tasmania 93: 165-183.

Guiler ER. 1960. The intertidal zone-forming species on the East Australian coast. The Journal of Ecology 48: 1-28.

Jara F \& CA Moreno. 1984. Herbivory and structure in a midlittoral rocky community: a case in southern Chile. Ecology 65: $28-38$

Lagos NA, JC Castilla \& BR Broitman. 2008. Spatial environmental correlates of intertidal recruitment: a test using barnacles in northern Chile. Ecological Monographs 78: 245-261.

Lewis JR. 1955. The mode of occurrence of the universal intertidal zones in Great Britain; with a comment by T.A. and Anne Stephenson. The Journal of Ecology 43: 270-290.

Lewis JR. 1964. The ecology of rocky shores, 323 pp. The English University Press, London.

Moreno CA \& E Jaramillo. 1983. The role of grazers in the zonation of intertidal macroalgae on the Chilean coast near Valdivia. Oikos 41: 73-76.

Moreno CA \& F Jara. 1984. Ecological studies on fish fauna associated with Macrocystis pyrifera belts in the south of Fueguian islands, Chile. Marine Ecology Progress Series 15: 99-107.
Moreno CA \& JP Sutherland. 1982. Physical and biological processes in a Macrocystis pyrifera community near Valdivia, Chile. Oecologia 55: 1-6.

Moreno CA, KM Lunecke \& MI Lopez. 1986. The response of an intertidal Concholepas concholepas (Gastropoda: Muricidae) to protection from man in southern Chile and its effects on benthic sessile assemblages. Oikos 46: 359-64.

Moreno CA, JP Sutherland \& F Jara. 1984. Man as a predator in the intertidal zone of southern Chile. Oikos 42: 155-160.

Montalva S \& B Santelices. 1981. Interspecific interference among species of Gelidium from central Chile. Journal of Experimental Marine Biology and Ecology 53: 77-88.

Ojeda FP \& B Santelices. 1984a. Invertebrate communities in holdfasts of the kelp Macrocystis pyrifera from southern Chile. Marine Ecology Progress Series 16: 65-73.

Ojeda FP \& B Santelices. 1984b. Ecological dominance of Lessonia nigrescens (Phaeophyta) in Central Chile. Marine Ecology Progress Series 19: 83-91.

Oliger P \& B Santelices. 1981. Physiological ecological studies on Chilean Gelidiales. Journal of Experimental Marine Biology and Ecology 53: 65-75.

Paine RT. 1966. Food web complexity and species diversity. The American Naturalist 100: 65-75.

Paine RT. 1986. Problemas antiguos y algunas nuevas perspectivas en ecología del bentos. Estudios Oceanológicos 5: 9-18.

Paine RT. 1994. Marine rocky shores and community ecology: An experimentalist's perspective. In: Kinne O (ed). Excellence in Ecology 4: 1-152. Ecology Institute, Oldendorf.

Paine RT \& AR Palmer. 1978. Sicyases sanguineus: a unique trophic generalist from the Chilean intertidal zone. Copeia 1978: 75-81.

Paine RT, JC Castilla \& J Cancino. 1985. Perturbation and recovery of starfish-dominated intertidal assemblages in Chile, New Zealand and Washington State. The American Naturalist 125: 679-691.

Pérès J \& J Picard. 1955. Biotopes et biocoenoses de la Méditerranée occidentale comparés à ceux de la Manche et de 1'Atlantique nord-oriental. Archives de Zoologie Expérimentale et Générale 92: 1-71.

Power ME, D Tilman, J Estes, BA Menge, LS Mills, WJ Bond, G Daily, J Lubchenco, JC Castilla \& RT Paine. 1996. Challenges in the quest for keystones. BioScience 46: 609-628.

Romo H \& KAlveal. 1977. Las comunidades del litoral rocoso de Punta Ventanilla, Bahía de Quintero, Chile. Gayana Miscelánea 6: 1-41.

Santelices B. 1980. Muestreo cuantitativo de comunidades intermareales de Chile Central. Archivos de Biología y Medicina Experimentales 13: 413-424.

Santelices B. 1981. Perspectivas de investigación en estructura y dinámica de comunidades intermareales rocosas de Chile 
Central. I. Cinturones de macroalgas. Medio Ambiente 5: 175-189.

Santelices B. 1991. Littoral and sublittoral communities of continental Chile. In: Mathieson AC \& PH Nienhuis (eds). Intertidal and Littoral Ecosystems of the World. Vol. 24. Ecosystems of the World, pp. 347-369. Elsevier Science Publishers, Amsterdam.

Santelices B \& FP Ojeda. 1984. Recruitment, growth and survival of Lessonia nigrescens (Phaeophyta) at various tidal levels in exposed habitats of Central Chile. Marine Ecology Progress Series 19: 73-82.

Santelices B, S Montalva \& P Oliger. 1981. Competitive algal community organization in exposed intertidal habitats from Central Chile. Marine Ecology Progress Series 6: 267-276.

Santelices B, JC Castilla, J Cancino \& P Schmiede. 1980. Comparative ecology of Lessonia nigrescens and Durvillaea antarctica (Pheophyta) in central Chile. Marine Biology 59: 119-132.
Southward AJ. 1958. The zonation of plants and animals on rocky shores. Biological Reviews 33: 137-177.

Stephenson TA. 1936. The marine ecology of the South African coast, with special reference to the habits of limpets. Proceedings of the Linnean Society of London 148: 7479.

Stephenson TA \& A Stephenson. 1949. The universal features of zonation between tidemarks on rocky coasts. Journal of Ecology 38: 289-305.

Stephenson TA \& A Stephenson. 1972. Life between tidemarks on rocky shores. 425 pp. W.H. Freeman, San Francisco.

Viviani CA. 1979. Ecogeografía del litoral chileno. Studies on Neotropical Fauna and Environment 14: 65-123.

Recibido el 7 de octubre de 2008 y aceptado el 14 de noviembre de 2008 